\title{
Laurence Moon Bardet Biedl Syndrome Presenting as Refractory Hyperkalaemia - Explore Everything
}

\author{
Maharshi Patel ${ }^{1}$, Dhruv Talwar², Aayush Dubey ${ }^{3}$, Sunil Kumar ${ }^{4}$ \\ 1,2,3,4 Department of Medicine, Jawaharlal Nehru Medical College, Sawangi (Meghe), Wardha, Maharashtra, India.
}

\section{INTRODUCTION}

Laurence Moon Bardet Biedl syndrome (LMBBS) / Bardet-Biedl disorder (BBS) is an uncommon hereditary disease that is autosomally recessive. It is described by obesity, mental hindrance, dysphoric furthest points (syndactyly, brachydactyly, or polydactyly), retinal dystrophy or retinitis pigmentosa, hypogonadism, and renal abnormalities (among the prevailing aspects). ${ }^{1}$ LMBBS shares its similarities with Oliver McFarlane syndrome [OMS].

Many patients experienced a gradual loss of vision as a result of retinitis pigmentosa. In retinitis pigmentosa, initially, patients will have night blindness which can be progressed into colour blindness and tunnel vision. Patients of LMBBS may have taurodontism, the condition in which the tooth's body is greater than the roots. ${ }^{2}$ Patients of LMBBS can develop chronic renal failure. ${ }^{3}$ Other features such as brachycephaly, learning disability and gait ataxia can be found in LMBBS patients. ${ }^{4}$

\section{PRESENTATION OF CASE}

A 24-year-old male presented with symptoms of breathlessness and pedal oedema which was gradual in onset. Upon asking the patient's father, he stated that breathlessness was aggravated by walking and relieved by taking rest. The patient had swollen legs which can be easily pitted.

The patient also had thick bushy eyebrows, hypodontia, taurodontism. He had polydactyly in the upper limb, but he was operated for it, but he has polydactyly in both the lower limbs. His parents' marriage was non-consanguineous, but his elder brother has the same features as him. The patient's father stated that he had a developmental delay and learning disability. The patient's father also stated that he has difficulty in seeing far objects and reading books, he has to read by holding the book close to his eyes.

Patient's previous reports revealed hyperkalaemia with normal kidney function since past six months which was refractory to the treatment he was receiving. He was not on angiotensin converting enzyme inhibitors (ACEI) or angiotensin receptor blockers (ARB) and he did not have any upper GI bleeding. On general examination, the patient's general condition was moderate, afebrile, pulse was $90 / \mathrm{min}$, BP was 160/110 mm Hg.

On systemic examination, CVS: S1 S2 heard, RS: bilateral clear, CNS: conscious and oriented, per abdomen: soft and non-tender. Fundus examination revealed bilateral retinitis pigmentosa. Oral examination revealed dental crowding, hypodontia, taurodontism, and a high arched palate.
Corresponding Author: Dr. Maharshi Patel, G-1, Raghobaji Boys Hostel, Jawaharlal Nehru Medical College, Sawangi (Meghe), Wardha, Maharashtra, India.

E-mail: maharship083@gmail.com

DOI: $10.14260 / j e m d s / 2021 / 601$

How to Cite This Article:

Patel M, Talwar D, Dubey A, et al. Laurence moon Bardet Biedl syndrome presenting as refractory hyperkalaemia - explore everything. J Evolution Med Dent Sci 2021;10(34):2945-2947, $10.14260 / \mathrm{jemds} / 2021 / 601$

Submission 11-04-2021,

Peer Review 16-06-2021,

Acceptance 23-06-2021,

Published 23-08-2021.

Copyright $($ C) 2021 Maharshi Patel et al. This is an open access article distributed under Creative Commons Attribution License [Attribution 4.0 International (CC BY 4.0)] 
On investigations, it reveals $\mathrm{Hb}: 6.1 \mathrm{gm} / \mathrm{dL}$, mean corpuscular volume (MCV): 90.8 , platelet count: $252000 / \mathrm{mm}^{3}$, white blood cells (WBC): $22600 / \mathrm{mm}^{3}$, red blood cell (RBC count): 2.06 million $/ \mathrm{mm}^{3}$, sodium: $147 \mathrm{meq} / \mathrm{L}$, potassium: 8.9 meq/L, serum urea: $256 \mathrm{mg} / \mathrm{dL}$, serum creatinine: $13 \mathrm{mg} / \mathrm{dL}$, total bilirubin: $0.3 \mathrm{mg} / \mathrm{dL}$, conjugated bilirubin: $0.1 \mathrm{mg} / \mathrm{dL}$, serum glutamic oxaloacetic transaminase (SGOT): $37 \mathrm{IU} / \mathrm{L}$, serum glutamic pyruvic transaminase (SGPT): $30 \mathrm{IU} / \mathrm{L}$, alkaline phosphatase: $1500 \mathrm{IU} / \mathrm{L}$. Urine routine microscopy was suggestive of pus cells: 2 - 3 cells/HPF and the presence of albumin. Arterial blood gases test (ABG) suggestive of metabolic acidosis.

USG abdomen and pelvis were suggestive of grade III renal parenchymal defect. On admission, the patient was in renal failure with uremic encephalopathy. Dialysis was done for 3 consecutive days and kidney function test (KFT) was monitored which showed a decreasing trend. The patient was started on injectable antibiotics and other supportive measures.

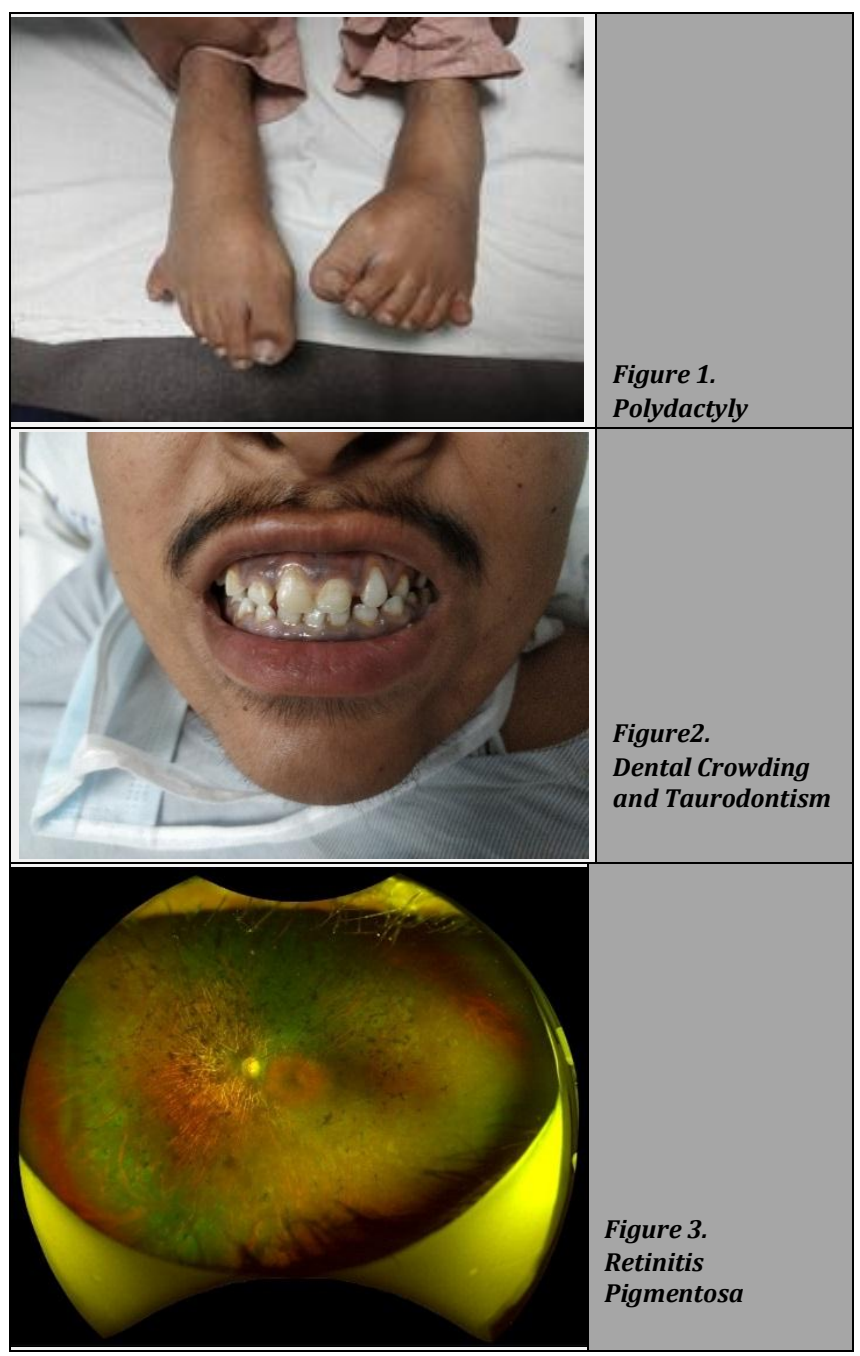

\section{DISCUSSION}

The first case was diagnosed by Laurence and Moon in 1866. Bardet and Biedl presented the patient with obesity, polydactyly in the early 1920 s.

The exact mechanism which can cause LMBBS is still unclear but there are 12 genes responsible for the syndrome which is BBS1-BBS12. BBS gene is responsible for ciliary transport and hence this syndrome falls into the category of "ciliopathy". 5 the main ones are BBS1 (11q13), BBS2 (16q22), BBS3 (3p13), and BBS4 (15q21). ${ }^{6}$

New diagnostic criteria were proposed by Beals et al. in 1999 which includes major criteria like visual disorders, limb defects, body mass index (BMI) $>25$, learning difficulties, renal tract abnormalities and minor criteria like developmental delay, neurologic and motor deficits, behavioural problems, speech deficits, hearing loss, dental anomalies, asthma, facial features, hypogonadism, diabetes mellitus and heart defects. ${ }^{7}$

Harnett JD et al. conducted study and they have observed functional and structural abnormalities of kidney. Some of them required hemodialysis. ${ }^{8}$

Hurley RM et al. observed that there is tubulointerstitial damage with medullary and cortical cysts similar to familial nephronophthisis. Apart from that, there is also mesangial proliferation with glomerular scarring. Thus, because of these changes they observed proteinuria and moderate renal failure in patients of LMBBS. ${ }^{9}$

Since potassium balance is dependent on GI intake and renal excretion, and there is kidney damage in LMBBS patients, we can find hyperkalaemia in these types of patients. Hyperkalaemia can manifest on electrocardiogram (ECG) with sinus bradycardia, ventricular tachycardia, ventricular fibrillation, AV block, asystole, slow idioventricular rhythm, sine wave and tall $\mathrm{T}$ wave. ${ }^{10}$

There is poor development of secondary sexual characteristics in many LMBBS patients, so puberty can be a stressful time for them. Testosterone supplements in the male patient might be helpful to overcome that problem. For visual problems and correction of refractive errors, spectacles and regular ophthalmological follow-ups should be advised to the patients. Accessory digits are non-functional and can be excised for cosmetic reasons. Low calorie and low protein diet can help in obesity control and can prevent the progression of renal failure.

\section{CONCLUSIONS}

Therefore, we conclude that Lawrence Moon Bardet Biedl syndrome with refractory hyperkalemia even though a rare phenomenon can be life threatening for the patient and hence needs to be diagnosed and treated promptly to prevent morbidity and mortality.

Financial or other competing interests: None.

Disclosure forms provided by the authors are available with the full text of this article at jemds.com.

\section{REFERENCES}

[1] Green JS, Parfrey PS, Harnett JD, et al. The cardinal manifestations of Bardet-Biedl syndrome, a form of Laurence-Moon-Biedl syndrome. New England Journal of Medicine 1989;321(15):1002-9.

[2] Khan PA, Nishaat J, Noor S, et al. Laurence - Moon - Bardet - Biedl syndrome: a rare case report in a tertiary care 
teaching hospital, Hyderabad, Telangana, India. Int J Med Public Health 2017;7(1):68-71.

[3] Williams B, Jenkins D, Walls J. Chronic renal failure: an important feature of the Laurence-Moon-Biedl syndrome. Postgraduate Medical Journal 1988;64(752):462-4.

[4] Joshi M, Jain V, Jajoo N, et al. Bardet - Biedl syndrome with gait ataxia: a case report. The Internet Journal of Internal Medicine 2007;7(2):1-4.

[5] Beales PL, Warner AM, Hitman GA, et al. Bardet - Biedl syndrome: a molecular and phenotypic study of 18 families. Journal of Medical Genetics 1997;34(2):92-8.

[6] Bruford EA, Riise R, Teague PW, et al. Linkage mapping in 29 Bardet-Biedl syndrome families confirms loci in chromosomal regions 11q13, 15q22. 3-q23 and 16q21. Genomics 1997;41(1):93-9.

[7] Beales PL, Elcioglu N, Woolf AS, et al. New criteria for improved diagnosis of Bardet - Biedl syndrome: results of a population survey. Journal of Medical Genetics 1999;36(6):437-46.

[8] Harnett JD, Green JS, Cramer BC, et al. The spectrum of renal disease in Laurence-Moon-Biedl syndrome. New England Journal of Medicine 1988;319(10):615-8.

[9] Hurley RM, Dery P, Nogrady MB, et al. The renal lesion of the Laurence - Moon - Biedl syndrome. The Journal of Pediatrics 1975;87(2):206-9.

[10] Kumar S. Hyperkalemia - slow and bizarre almost fatal track. International Journal of Clinical Cases and Investigations 2013;5(3):24-5. 